\title{
The Effect of a Class Visit Supervision Workshop on the Pedagogic Abilities of Basic School Teachers Assessed from Early Pedagogic Ability in Rantau Selatan District, Labuhanbatu District
}

\author{
Menneria Pane ${ }^{1}$, Ajat Sudrajat ${ }^{2}$, Titi Chandra wati ${ }^{3}$ \\ ${ }^{1,3}$ Universitas Terbuka, Indonesia \\ ${ }^{2}$ Universitas Negeri Medan, Indonesia \\ menneria.pane@gmail.com
}

\begin{abstract}
This type of research used in this research is experimental quantitative research. To find out the effect of the classroom visit supervision workshop and teacher certification on the pedagogical ability of elementary school teachers in terms of the initial pedagogical ability in Rantau Selatan District. The population in this study was elementary school teachers in Rantau Selatan District, Labuhanbatu Regency, totalling 377 teachers spread over 23 locations. The sample in this study was 60 teachers. From the research results, it can be concluded that the magnitude of the simultaneous influence of the implementation of the supervisory workshop and the initial ability to the pedagogical ability of teachers is $66.4 \%$ while the remaining $33.6 \%$ is influenced by other factors outside of the two variables observed in this study.
\end{abstract}

Keywords

workshop on class visit supervision; pedagogic ability; initial pedagogic ability

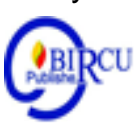

\section{Introduction}

Pedagogy is the science that studies how to guide children, how better educators should deal with students, what is the task of educators in educating children, what is the goal of educating children. This section will discuss the pedagogical meaning of education in a special sense and in a broad sense. In the pedagogical competence, it is stated that a teacher must be able to use and utilize information and communication technology for the benefit of learning (Yusrizal et al., 2017)

Education contains three aspects, namely educating, teaching and training. However, in reality there are still many elementary school teachers in Rantau Selatan District, consisting of 19 state schools and 4 private schools who have not been able to properly compile lesson plans, both PNS and non PNS teachers as well as certified and non-certified teachers on average only doing copy and paste from the internet which is actually very incompatible with the conditions at school so this automatically affects the quality of the output produced in the learning process. Simanjuntak (2020) states that education in Indonesia is expected to prepare students to become citizens who have a strong and consistent commitment to defending the Unitary State of the Republic of Indonesia. Quality education will produce humans who have superior and independent abilities. Education is a process of development, formation, and guidance practical training for humans through appropriate guidance and guidance throughout his life (Utomo, 2020). But in reality, the quality of education in Indonesia is not experiencing significant progress Sugiharto (2020). 
According to Suwarno (2009) that pedagogy is education that emphasizes educational practice, in this case it is closely related to the activities of educating and guiding children. Meanwhile, the meaning of pedagogy according to Sarwono is a theory that carefully, objectively and critically develops the concept of human nature, the essence of children, the essence of children, and the essence of the process of educational goals themselves. Given the large role of teachers in the educational process, principals as direct supervisors are required to have the main capacity as educators, managers, administrators, supervisors, leaders, innovators, and motivators.

The position of the principal as administrator, manager, and supervisor in the school has a role to regulate, organize, and utilize all resources owned by 8 schools to achieve predetermined goals. Therefore, to get a quality principal can be taken from a quality teacher, who is competent and experienced as a teacher (direct experimental learning).

Teaching experience in school alone is not enough to become a quality principal, but there needs to be preparation through principal training related to the duties as a supervisor to be carried out and the experience of being a school principal. Davis and Thomas (1989) stated that: " The most effective principles are related to (a) leadership traits and skills, (b) problem solving abilities, (c) social skills, or (d) professional knowledge and competence ". with the understanding that: The most effective principal is related to (a) leadership traits and skills, (b) problem-solving abilities, (c) social skills, or (d) professional knowledge and competence.

In the practice of supervision activities, there are various approaches, including collaborative supervision, clinical supervision, collegial supervision, supervisory visits to classroom, and informal supervision. There is no strategy, model or procedure that is the best in supervision activities, each approach has advantages besides disadvantages. From several approaches to supervision, the researcher chose a classroom visit supervision workshop. The classroom visit approach in supervision, the principal can immediately know the learning process in the classroom and dialogue is carried out between the teacher and the principal to find out the successes and weaknesses.

Competence is a set of abilities to perform a position, and not merely knowledge. Meanwhile, a set of competencies that must be possessed by teachers includes personality competence, pedagogical competence, professional competence, and social competence. The teacher's mastery of the four competencies is expected to support the implementation of tasks in schools, especially in improving the quality of student learning. The overall competencies possessed by teachers are not only mastered conceptually but need to be actualized in real activities in schools and in the community, given the increasingly real demands of society for the quality of education graduates.

From the description above, it can be used as a strong reason for researchers to conduct research on workshop supervision of class visits and teacher certification on the pedagogical abilities of elementary school teachers in terms of initial pedagogical abilities in Rantau Selatan District. Other reasons that become the rationale for conducting research are as follows: 1) decentralization of education is at the level of the education unit so that the principal is given the authority to empower school resources, especially teachers in achieving educational goals; 2) the principal is responsible for the quality of learning carried out by the teacher, it is obligatory to carry out a programmed classroom visit supervision workshop; 3 ) the principal is able to assess the difference in professionalism of certified and non-certified teachers; and 4) pedagogical abilities can develop if supported by a conducive school atmosphere. The school principal held dialogue in a democratic and transparent manner. 


\section{Review of Literatures}

\subsection{Teacher Pedagogic Ability}

Pedagogic Competence is one type of competency that absolutely needs to be mastered by teachers. Pedagogic Competence is basically the ability of teachers to manage student learning. Pedagogic Competence is a distinctive competency, which will differentiate teachers from other professions and will determine the level of success of the process and learning outcomes of their students.

This competence is not obtained suddenly but through continuous and systematic learning efforts, both during the pre-service period (education for prospective teachers) and during their tenure, which is supported by the talents, interests and other potential of each individual teacher. The initial ability (prior knowledge) is a collection of individual knowledge and experiences acquired during their life journey, which they will bring to a new learning experience. The initial ability of a teacher will affect the learning process. The science of learning called the pedagogic, it has a broader context of basic skills teaching (teaching skills). Pedagogy does not only plan, implement, and evaluate student learning processes and outcomes, but also includes other aspects of learning that support the improvement of the quality of learning outcomes.

A teacher in carrying out the learning process in the classroom is an integral part of the pedagogical competencies that every educator and teacher must possess. It is a common belief that the management of the learning process must be carried out and even developed based on knowledge and skills because it is impossible for the learning process to be successful without the support of smart management.

Therefore, every teacher must know, understand, and believe in the importance of teaching and learning knowledge of their students, including appreciating them by training themselves how to teach students effectively, both before entering class, during class, and after leaving. from class. Indeed, the level of urgency changes with the maturity and integrity of learners' own learning.

Based on Law Number 14 of 2005 concerning Teachers and Lecturers, Article 10 paragraph (1) states that "Teacher competence as referred to in Article 8 includes pedagogical competence, personality competence, social competence, and professional competence obtained through professional education". Pedagogic Competence is the ability to understand students, design and implement learning, evaluate learning outcomes, and develop students to actualize their various potentials.

\subsection{Supervision Workshop}

An educational workshop is a group learning activity consisting of education officers who solve problems faced by means of conversations and work in groups or individually. Workshop or workshop is one method that can be taken by the principal in carrying out managerial supervision. This method is of course a group and can involve several teachers based on guidance and supervision sheets by the supervisor directly in designing lesson plans that will be carried out in the learning process in class. The organization of this workshop is of course tailored to its purpose or urgency, and can be held together with all teachers at SDN 08 Rantau Selatan. This supervision workshop uses training based on indicators or steps regarding concepts, principles, approaches, techniques, models, instruments and stages of classroom visit supervision.

Sah understanding (2008) distinguishes supervision techniques into two, namely supervision techniques that are individual and group. There are three types 
of individual supervision techniques, namely: (1) class visits, (2) observation, (3) private conversations. Meanwhile, group techniques include: teacher meetings, group discussions, workshops, seminars, symposiums, and so on. According to Nawawi (1995), supervision of class visits is part of school visit activities, because in the same sense as supervision of class visits. Meanwhile, Rohmadi (2004) states that classroom visit supervision is one of the supervision techniques aimed directly at teachers for improving teaching methods, using teaching aids, student collaboration in class and others. Based on some of the opinions above, it can be concluded that classroom visit supervision is to help teachers in solving the difficulties they face. In class visits, the priority is to learn about the nature and quality of children's learning methods and how teachers guide their students. Because of its nature of studying and conducting class reviews, it is often called classroom observation.

According to Rivai (in Kadim, 2012: 59) that the characteristics of supervision planning are as follows: 1) supervision has no standard plan; 2) planning supervision requires creativity; 3) comprehensive; 4) cooperative; and 5) flexible. Furthermore, Kadim (2012: 62) states that the factors required in the planning of supervision are: 1) clarity of educational objectives in schools; 2) knowledge of effective teaching; 3) knowledge of children (students); 4) knowledge of teachers; 5) knowledge of potential sources of supervision activities; and 6) the ability to calculate time.

\section{Research Method}

This type of research is a quasy experiment with a $2 \times 2$ factorial design. This research was carried out by elementary schools in Rantau Selatan District, totalling 23 public and private elementary schools. The population in this study were elementary school teachers in Rantau Selatan District, Labuhanbatu Regency, totalling 377 teachers spread over 23 locations. The sample is $15 \%$ from 377 teachers. Thus the number of samples in this study was 60 . The data collection technique used in this study was a test. The data analysis technique used in this research is inferential statistical techniques. Hypothesis testing is done by using the Two Way Anova test with a significant level of 0.05. Before the Two Way Anova test is carried out, first the analysis requirements test is carried out, namely the normality test and the homogeneity test of the data. The normality test was performed using the Shapiro-Wilk test, while the data homogeneity test was carried out by the Levene test with a significant level of 0.05 .

\section{Results and Discussion}

\subsection{Results}

In this study, what is meant by the Initial Teacher Pedagogic Ability is the basic ability of each teacher, namely before the School Principal conducts the workshoop supervision of class visits. The basic abilities meant here are related to the completeness of teacher administration, questioning skills, skills to provide reinforcement, variations in skills, explaining skills, opening and closing lessons, guiding skills for small group discussions, class management skills, and small group and individual teaching skills. The data on the initial pedagogical ability of teachers is in the form of secondary data taken from the teacher supervision assessment results documents available in each school. 
Table 1. Data Description of Teacher's Initial Ability and Pedagogic Ability

\begin{tabular}{|c|c|c|c|c|c|}
\hline \multicolumn{6}{|c|}{ Statistics } \\
\hline & & $\begin{array}{l}\text { Initial Ability of } \\
\text { Teachers Not } \\
\text { Following the } \\
\text { Workshop }\end{array}$ & $\begin{array}{c}\text { Initial Ability of } \\
\text { Teachers who Attend } \\
\text { the Workshop }\end{array}$ & $\begin{array}{l}\text { Value of Pedagogic } \\
\text { Ability of Non- } \\
\text { Supervised } \\
\text { Teachers }\end{array}$ & $\begin{array}{l}\text { Teachers Pedagogic } \\
\text { Capability Value } \\
\text { Y an g Following } \\
\text { Supervision }\end{array}$ \\
\hline \multirow[t]{2}{*}{$\overline{\mathrm{N}}$} & Valid & 30 & 30 & 30 & 30 \\
\hline & Missing & 0 & 0 & 0 & 0 \\
\hline \multicolumn{2}{|c|}{ Mean } & 57.47 & 62.53 & 74.53 & 85.47 \\
\hline \multicolumn{2}{|c|}{ Median } & 57.50 & 62.50 & 75.00 & 85.00 \\
\hline \multicolumn{2}{|c|}{ Mode } & $57^{\mathrm{a}}$ & $62^{a}$ & 78 & 81 \\
\hline \multicolumn{2}{|c|}{ Std. Deviation } & 1.697 & 1.676 & 3.954 & 3.963 \\
\hline \multicolumn{2}{|c|}{ Variance } & 2.878 & 2.809 & 15.637 & 15.706 \\
\hline \multicolumn{2}{|c|}{ Minimum } & 54 & 60 & 66 & 80 \\
\hline \multicolumn{2}{|c|}{ Maximum } & 61 & 66 & 80 & 94 \\
\hline \multicolumn{2}{|c|}{ Sum } & 1724 & 1876 & 2236 & 2564 \\
\hline
\end{tabular}

a. Multiple modes exist. The smallest value is shown

From the table above it can be seen that the average (mean) initial pedagogic ability of teachers who did not attend the supervision workshop was 57.47 or lower than the pedagogic average of teachers who attended the supervision workshop, which was 62.53 .

Table 2. Frequency Distribution of the Initial Ability of Teachers who did not attend the Workshop

Initial Ability of Teachers Not Following the Workshop

\begin{tabular}{|c|c|c|c|c|c|}
\hline & & Frequency & Percent & Valid Percent & Cumulative Percent \\
\hline \multirow{9}{*}{$\overline{\text { Valid }}$} & 54 & 1 & 3.3 & 3.3 & 3.3 \\
\hline & 55 & 3 & 10.0 & 10.0 & 13.3 \\
\hline & 56 & 5 & 16.7 & 16.7 & 30.0 \\
\hline & 57 & 6 & 20.0 & 20.0 & 50.0 \\
\hline & 58 & 6 & 20.0 & 20.0 & 70.0 \\
\hline & 59 & 6 & 20.0 & 20.0 & 90.0 \\
\hline & 60 & 2 & 6.7 & 6.7 & 96.7 \\
\hline & 61 & 1 & 3.3 & 3.3 & 100.0 \\
\hline & Total & 30 & 100.0 & 100.0 & \\
\hline
\end{tabular}

From table 2, data on the initial ability scores of teachers who did not attend the workshop with a value of 54 were 1 person, a value of 55 was 30 people, a score of 56 was 5 people, a score of 57 was 6 people, a score of 58 was 6 people, a score of 59 was 6 people, 2 people scored 60 and 1 person scored 61.

Table 3. Frequency Distribution of the Initial Ability Values of Teachers who attend the Workshop

\section{Initial Ability of Teachers who Attend the Workshop}

\begin{tabular}{l|r|r|r|r} 
& Frequency & \multicolumn{1}{c|}{ Percent } & Valid Percent & \multicolumn{1}{c}{ Cumulative Percent } \\
\hline Valid & 4 & 13.3 & 13.3 & 13.3 \\
\hline 60 & 5 & 16.7 & 16.7 & 30.0 \\
\hline 61 & 6 & 20.0 & 20.0 & 50.0 \\
\hline 63 & 6 & 20.0 & 20.0 & 70.0 \\
\hline 64 & 5 & 16.7 & 16.7 & 86.7 \\
\hline 65 & 3 & 10.0 & 10.0 & 96.7 \\
\hline 66 & 1 & 3.3 & 3.3 & 100.0 \\
\hline Total & 30 & 100.0 & 100.0 & \\
\hline
\end{tabular}


From table 3, the data obtained from the initial pedagogic ability value of teachers who participated in the supervision workshop was with a value of 60 as many as 4 people, a value of 61 as many as 5 people, a value of 62 as many as 6 people, a value of 63 as many as 6 people, a value of 64 as many as 5 people, a value of 65 as many as 3 people, and the value of 66 is 1 person.

Table 4. Pedagogic Values of Teachers Who Do Not Attend Supervision Workshops

Value of Pedagogic Ability of Non-Supervised Teachers

\begin{tabular}{|r|r|r|r|r}
\hline & Frequency & Percent & Valid Percent & Cumulative Percent \\
\hline Valid & 1 & 3.3 & 3.3 & 3.3 \\
\hline 66 & 1 & 3.3 & 3.3 & 6.7 \\
\hline 68 & 1 & 3.3 & 3.3 & 10.0 \\
\hline 69 & 1 & 3.3 & 3.3 & 13.3 \\
\hline 70 & 1 & 3.3 & 3.3 & 16.7 \\
\hline 71 & 2 & 6.7 & 6.7 & 23.3 \\
\hline 72 & 2 & 6.7 & 6.7 & 30.0 \\
\hline 73 & 2 & 6.7 & 6.7 & 36.7 \\
\hline 74 & 2 & 6.7 & 6.7 & 43.3 \\
\hline 75 & 3 & 10.0 & 10.0 & 53.3 \\
\hline 76 & 3 & 10.0 & 10.0 & 63.3 \\
\hline 77 & 2 & 6.7 & 6.7 & 70.0 \\
\hline 78 & 4 & 13.3 & 13.3 & 83.3 \\
\hline 79 & 3 & 10.0 & 10.0 & 93.3 \\
\hline 80 & 2 & 6.7 & 6.7 & 100.0 \\
\hline Total & 30 & 100.0 & 100.0 & \\
\hline
\end{tabular}

From table 4, it is obtained the score data on the results of supervision of the pedagogic ability of teachers who did not attend the workshop, namely: with a value of 66 as many as 1 person, a value of 67 as much as 1 people, a value of 68 by 1 person, a value of 69 as many as 1 person, a value of 70 as much as 1 person, a value of 712 people, 2 scores of 72, 2 points of 73, 2 of 74, 3 of 75, 3 of 76, 2 of 77, 3 of 78, 3 of 792 people and 80 .

Table 5. Pedagogic Values of Teachers who attend the Supervision Workshop The Value of the Pedagogic Ability of Teachers who Follow

\section{Supervision}

\begin{tabular}{rrr|r|r|r} 
& Frequency & Percent & Valid Percent & Cumulative Percent \\
\hline Valid & 2 & 6.7 & 6.7 & 6.7 \\
\cline { 2 - 6 } & 80 & 4 & 13.3 & 13.3 & 20.0 \\
\hline 81 & 2 & 6.7 & 6.7 & 26.7 \\
\hline 82 & 3 & 10.0 & 10.0 & 36.7 \\
\hline 83 & 3 & 10.0 & 10.0 & 46.7 \\
\hline 84 & 3 & 10.0 & 10.0 & 56.7 \\
\hline 85 & 2 & 6.7 & 6.7 & 63.3 \\
\hline 86 & 2 & 6.7 & 6.7 & 70.0 \\
\hline 87 & 2 & 6.7 & 6.7 & 76.7 \\
\hline 88 & 2 & 6.7 & 6.7 & 83.3 \\
\hline 89 & 1 & 3.3 & 3.3 & 86.7 \\
\hline 90 & 1 & 3.3 & 3.3 & 90.0 \\
\hline 91 & 1 & 3.3 & 3.3 & 93.3 \\
\hline 92 & 1 & 3.3 & 3.3 & 96.7 \\
\hline 93 & 1 & 3.3 & 3.3 & 100.0 \\
\hline 94 & 30 & 100.0 & 100.0 & \\
\hline Total & & & & \\
\hline
\end{tabular}


From table 5 data showed the ability of pedagogic Teachers who have participated in workshops supervision: with 80 as much as 2, the value of 81 of 4 people, the value of 82 as much as 2, a value of 83 for 3 people, the value of 84 were 3 people, the value of 85 were 3 people, 2 points of 86,2 of 87,2 of 88,1 of 90,1 of 91,1 of 92,1 of 93 , and 94 as many as 1 person.

Table 6. Results of Analysis Capabilities Data Description Start and End Capabilities Pedagogic Teacher

Statistics

\begin{tabular}{|c|c|c|c|}
\hline & & Early Pedagogic Abilities & Final Pedagogic Ability \\
\hline & Valid & 60 & 60 \\
\hline & Missing & 0 & 0 \\
\hline N & Mean & 60.00 & 80.00 \\
\hline \multicolumn{2}{|c|}{ Median } & 60.00 & 80.00 \\
\hline \multicolumn{2}{|c|}{ Mode } & $57 \mathrm{a}$ & $78 \mathrm{a}$ \\
\hline \multicolumn{2}{|c|}{ Std. Deviation } & 3,053 & 6,767 \\
\hline \multicolumn{2}{|c|}{ Variance } & 9,322 & 45,797 \\
\hline \multicolumn{2}{|c|}{ Minimum } & 54 & 66 \\
\hline \multicolumn{2}{|c|}{ Maximum } & 66 & 94 \\
\hline \multicolumn{2}{|c|}{ Sum } & 3600 & 4800 \\
\hline
\end{tabular}

a. Multiple modes exist. The smallest value is shown

From table 6 in the above it can be seen that the value of the average (mean) of the initial capabilities pedagogical teacher is 60 , and the average ability of the end is 80 . Similarly, the minimum value of the initial capability is 54 , while the minimum value is 66 or end capabilities to grow 12 points high. The same is true for the value/highest score/maximum of teachers' pedagogic abilities, which increased from 66 to 94 . This could happen, possibly because there was treatment in the form of a supervisory workshop for 30 teachers.

Table 7. Teacher's Initial Pedagogical Ability Scores

Early Pedagogic Abilities

\begin{tabular}{ccc|c|c|c}
\multicolumn{2}{c}{ Frequency } & Percent & Valid Percent & Cumulative Percent \\
\hline Valid & 54 & 1 & 1.7 & 1.7 & 1.7 \\
\cline { 2 - 6 } & 55 & 3 & 5.0 & 5.0 & 6.7 \\
\cline { 2 - 6 } & 56 & 5 & 8.3 & 8.3 & 15.0 \\
\hline 57 & 6 & 10.0 & 10.0 & 25.0 \\
\hline 58 & 6 & 10.0 & 10.0 & 35.0 \\
\hline 59 & 6 & 10.0 & 10.0 & 45.0 \\
\hline 60 & 6 & 10.0 & 10.0 & 55.0 \\
\hline 61 & 6 & 10.0 & 10.0 & 65.0 \\
\hline 62 & 6 & 10.0 & 10.0 & 75.0 \\
\hline 63 & 6 & 10.0 & 10.0 & 85.0 \\
\hline 64 & 5 & 8.3 & 8.3 & 93.3 \\
\hline 65 & 3 & 5.0 & 5.0 & 98.3 \\
\hline 66 & 1 & 1.7 & 1.7 & 100.0 \\
\hline
\end{tabular}

From table 7, it can be seen that the initial pedagogical abilities of the teachers who were sampled in this study were: the value of 54 as many as 1 person, the value of 55 as many as 3 people, the value of 56 as many as 5 people, the value of 57 to the value of 63 each as many as 6 people, the value 64 as many as 5 people, the value of 65 as many as 3 
people and the value of 66 as many as 1 person. The following is a diagram of the teacher's initial abilities as the sample in this study.

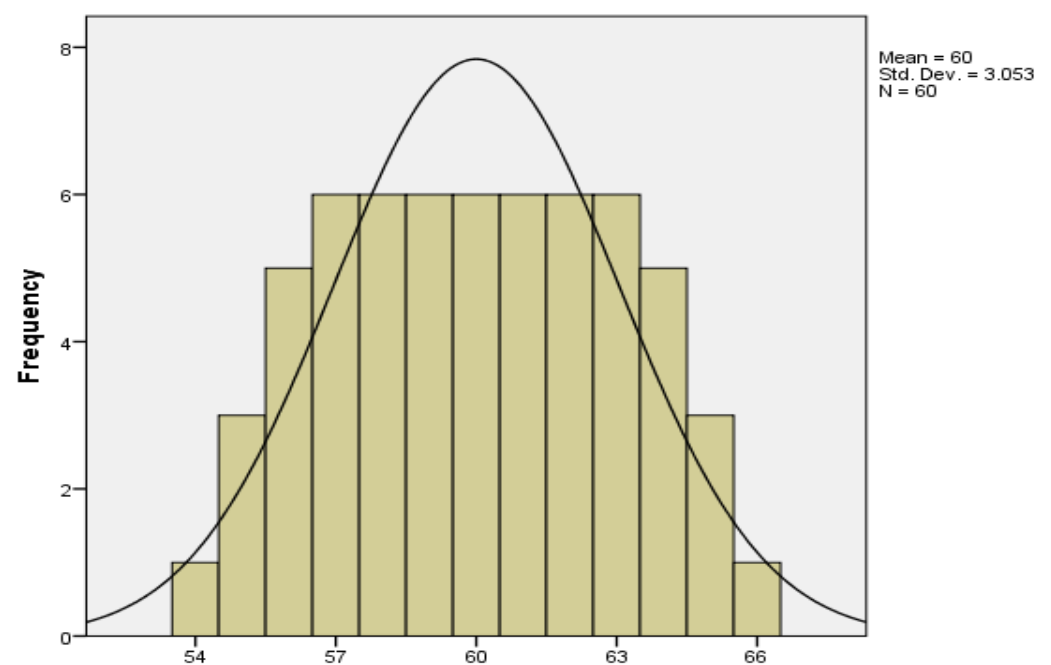

Figure 1. Bar Chart of Teacher's Initial Pedagogic Ability

Table 8. Score Results of Teacher Pedagogic Value

Final Pedagogic Ability

\begin{tabular}{|c|c|c|c|c|c|}
\hline \multirow{2}{*}{$\overline{\text { Valid }}$} & & Frequency & Percent & Valid Percent & Cumulative Percent \\
\hline & 66 & 1 & 1.7 & 1.7 & $\begin{array}{ll} & 1.7\end{array}$ \\
\hline & 67 & 1 & 1.7 & 1.7 & 3.3 \\
\hline & 68 & 1 & 1.7 & 1.7 & 5.0 \\
\hline & 69 & 1 & 1.7 & 1.7 & 6.7 \\
\hline & 70 & 1 & 1.7 & 1.7 & 8.3 \\
\hline & 71 & 2 & 3.3 & 3.3 & 11.7 \\
\hline & 72 & 2 & 3.3 & 3.3 & 15.0 \\
\hline & 73 & 2 & 3.3 & 3.3 & 18.3 \\
\hline & 74 & 2 & 3.3 & 3.3 & 21.7 \\
\hline & 75 & 3 & 5.0 & 5.0 & 26.7 \\
\hline & 76 & 3 & 5.0 & 5.0 & 31.7 \\
\hline & 77 & 2 & 3.3 & 3.3 & 35.0 \\
\hline & 78 & 4 & 6.7 & 6.7 & 41.7 \\
\hline & 79 & 3 & 5.0 & 5.0 & 46.7 \\
\hline & 80 & 4 & 6.7 & 6.7 & 53.3 \\
\hline & 81 & 4 & 6.7 & 6.7 & 60.0 \\
\hline & 82 & 2 & 3.3 & 3.3 & 63.3 \\
\hline & 83 & 3 & 5.0 & 5.0 & 68.3 \\
\hline & 84 & 3 & 5.0 & 5.0 & 73.3 \\
\hline & 85 & 3 & 5.0 & 5.0 & 78.3 \\
\hline & 86 & 2 & 3.3 & 3.3 & 81.7 \\
\hline & 87 & 2 & 3.3 & 3.3 & 85.0 \\
\hline & 88 & 2 & 3.3 & 3.3 & 88.3 \\
\hline & 89 & 2 & 3.3 & 3.3 & 91.7 \\
\hline & 90 & 1 & 1.7 & 1.7 & 93.3 \\
\hline & 91 & 1 & 1.7 & 1.7 & 95.0 \\
\hline & 92 & 1 & 1.7 & 1.7 & 96.7 \\
\hline & 93 & 1 & 1.7 & 1.7 & 98.3 \\
\hline & 94 & 1 & 1.7 & 1.7 & 100.0 \\
\hline & Total & 60 & 100.0 & 100.0 & \\
\hline
\end{tabular}


From table 8 it can be seen that the final score of the pedagogic ability of all teachers is: a value of 66 to 70 for 1 person, a value of 71 to 74 for 2 people each, a value of 75 and a value of 76 for 3 people each, the value 77 as many as 2 people, with scores of 78,80 and 81 each as many as 4 people, scores of $79,83,84,85$ each of 3 people, scores of 86 to 89 of 2 people each, and scores of 90 to value 94 each 1 person. The following is a bar chart (histogram) image of the teacher's pedagogic score / final score data.

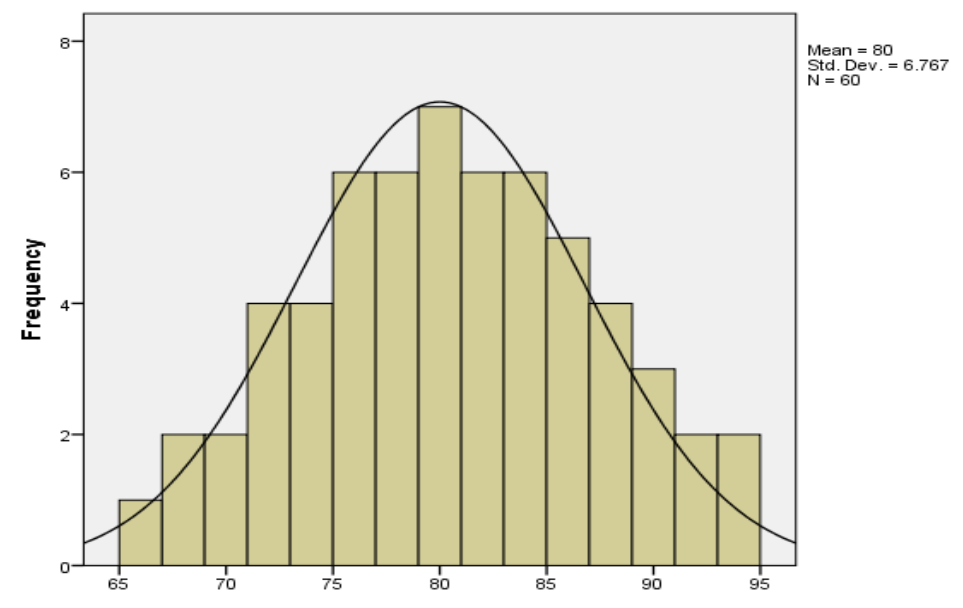

Figure 2. Diagram of the Teacher's Pedagogical Final Ability

Table 9. Linearity Test of Initial Ability to Final Pedagogic Ability of Teachers

\begin{tabular}{|c|c|c|c|c|c|c|c|}
\hline & & & VA Tabl & & & & \\
\hline & & & Sum of & & Mean & & \\
\hline & & & Squares & Df & Square & $\mathrm{F}$ & Sig. \\
\hline Late Pedagogic & Between & (Combined) & 2625,419 & 12 & 218,785 & 134,275 & .000 \\
\hline Ability * Early & Groups & Linearity & 2604,057 & 1 & 2604,057 & 1598,187 & .000 \\
\hline Pedagogic Ability & & Deviation from & 21,362 & 11 & 1,942 & 1,192 & .319 \\
\hline & & Linearity & & & & & \\
\hline & & & 76,581 & 47 & 1,629 & & \\
\hline & & & 2702000 & 59 & & & \\
\hline & Total & & & & & & \\
\hline
\end{tabular}

From the output table above, it can be seen that the sig. Deviation from Linearity is = $0.319 ;(0.419>0.05)$, meaning it can be ensured that there is a linear relationship between prior knowledge of pedagogy $\mathrm{k}$ teacher with the ability to end after treatment workshop supervision. Likewise, seeing the value of $\mathrm{F}$, namely $=1.192$; and the F-table for $\mathrm{df}=2$ and $n=60$ is $=3.15$; so that the F-count $<$ F-table is obtained so that it can be ascertained that there is a significant linear relationship between the variables of the initial ability and the final pedagogical ability of the teacher.

\subsection{Disculssion}

Supervision is a professional activity carried out by the Principal or School Superintendent in the framework of assisting school principals, teachers and other education personnel to improve the quality and effectiveness of education and learning delivery. Supervision is aimed at two aspects, namely: managerial and academic. Managerial supervision focuses on observations on aspects of management and administration of the School which serves as a support (supporting) the implementation of 
learning. Supervision must be carried out on an ongoing basis. Supervision is not a side task that is only done occasionally if there is an opportunity (Alfonso et al., 1981 and Weingartner, 1973).

Improving the quality of education at the level of education is very necessary for the implementation of supervision. Supervision is one of the main tasks in educational administration, not only the job of the inspectors or supervisors, but the principal's duty to the employees at the school. Teachers have a broad influence in the world of education, in schools the teacher is the implementer of education administration, which is responsible for education to take place well. Teachers are required to have academic qualifications, competencies, educator certificates, be physically and mentally healthy, and have the ability to realize the goals of national education (Zainal, 2009).

In this study, the data on the pedagogical ability of teachers who participated in the supervision workshop were the results of the supervision sheets that were filled in by the principal as the supervisor at the time of the research. In chapter III it is explained that the workshops are categorized as teachers who attend classroom visit supervision and teachers who do not attend the supervision workshop, the scores for teachers who attend the supervision workshop are obtained with an average score or mean $(\bar{x})=85.47$; and for teachers who do not attend the workshop obtained an average score or mean $(\bar{x})=74.53$.

The pedagogical ability of teachers with the initial pedagogic ability score consists of 2 categories, namely high and low. This data is taken from the document of teacher assessment results stored in each school. Data were obtained for the initial pedagogical ability scores of teachers who were later used as groups that took part in the supervision workshop, namely with an average score or mean $(\bar{x})=62.53$; while for the teacher group who would later be used as a control group (not participating in the supervision workshop) had an average score average or mean $(\bar{x})$ pedagogic ability, namely $=57.47$.

From the results of this data description, it can be seen that the implementation of the supervision workshop greatly influences the improvement of teacher pedagogic abilities, where for the group of teachers who did not attend the supervise workshop increased from 62.47 to 74.85 while the teacher who attended the supervision workshop had an increase from 62,85 becomes 85.47 .

The research findings based on the results of data processing can be concluded that the pedagogical ability of elementary school teachers in Rantau Selatan District is jointly influenced by the classroom visit supervision workshop by the principal, where teachers who participate in the supervision workshop activities can significantly improve their pedagogical abilities. Of the two variables studied (workshop supervision of class visits and teacher's initial pedagogical ability) have a direct influence on teacher pedagogical ability which is analogous to the teaching achievement of teachers.

\section{Conclusion}

Based on the results of research and discussion, several conclusions can be drawn including the following:

1. From the research results $t_{\text {count }}$ for $X_{1}$ (effect of supervision workshop implementation $)=10.697$, while $t$ table for $(0.025 ; 57)=2.002 \rightarrow(10.697>2.002)$ or $\mathrm{t}_{\text {count }}>\mathrm{t}_{\text {table }}$ or sig value. $=0.00 \rightarrow($ sig. $<0.05)$ means reject $\mathrm{H}_{0}$ and accept $\mathrm{H}_{1}$, which is "there is an effect of the implementation of the supervision workshop on the pedagogical ability of teachers". 
2. The value of $t_{\text {count }}$ variable $X_{2}$. From the table it can be seen that $t_{\text {count }}$ for $X_{2}=$ 22.266. While $t_{\text {table }}=2.002 \rightarrow(22.266>2.002)$ or $t_{\text {count }}>t_{\text {table }}$ or sig. $=0.00 \rightarrow$ (sig. $<0.05$ ) means accept $\mathrm{H}_{2}$, namely "there is an effect of the initial ability on the pedagogic ability of teachers"

3. Value $\mathrm{F}_{\text {count }}=793.196 \mathrm{~F}$ the table was for $(2 ; 58)=3.16 \rightarrow(793.196>3.16)$ or $\mathrm{F}_{\text {count }}$ $>\mathrm{F}_{\text {the table was }}$ or sig. $<0.05$; meaning it can be inferred thank $\mathrm{H}_{3}$ that "there is no influence of the workshop supervision simultaneously with the start of the ability pedagogic ability of teachers", it can be concluded that the magnitude of the simultaneous influence of the implementation of the supervision workshop and the initial ability to the pedagogic ability of teachers is $66.4 \%$. While the remaining $33.6 \%$ is influenced by other factors outside of the two variables observed in this study.

4. The value of $F_{\text {count }}=793,196$ while the $F_{\text {table }}$ for $(2 ; 58)=3.16 \rightarrow(793,196>3,16)$ or $\mathrm{F}_{\text {-count }}>\mathrm{F}_{\text {-table }}$ or sig. $<0.05$; It means that it can be concluded that $\mathrm{H}_{3}$ acceptance is "there is an effect of the implementation of the supervisory workshop simultaneously with the initial ability on the pedagogic ability of teachers". It can be concluded that the magnitude of the simultaneous influence of the implementation of the supervision workshop and the initial ability to the pedagogic ability of teachers is $66.4 \%$. While the remaining $33.6 \%$ is influenced by other factors outside of the two variables observed in this study. 


\section{References}

Alfonso. R. J. G.R. Firth, dan R.F. Neville. (1981). Instructional Supervision: A Behavioral System. Boston: Allyn and Bacon, Inc.

Davis, G. \& Thomas, M. (1989). Effective Schools and Effective Teacher. Boston: Allyn and Bacon.

Nawawi, Hadari. (1995). Administrasi Pendidikan, Jakarta: Toko Gunung Agung.

Rohmadi, Muhammad. (2004). Pragmatik Teori dan Analisis. Yogyakarta: Lingkae Media.

Sahertian, A Piet. (2008). Konsep Dasar dan Teknik Supervisi, Jakarta : Penerbit Rineka Cipta.

Simanjuntak, L., Sriadhi, and Saragi, D. (2020). The Effect of Project Based Learning Models and Learning Motivation on Civics Learning Results in 4th Grade Primary School 106163 Percut Sei Tuan. Budapest International Research and Critics in Linguistics and Education (BirLE) Journal Vol 3 (3): 1509-1520.

Sugiharto (2020) Geographical students' learning outcomes on basic political science by using cooperative learning model with Group Investigation (GI) type in State University of Medan, Indonesia, Journal of Human Behavior in the Social Environment, 30:4, 447-456, DOI: 10.1080/10911359.2019.1696261.

Suwarno, Wiji. (2009). Dasar-dasar Ilmu Pendidikan. Yogyakarta: Ar Ruzz Media.

Utomo, M.R., Hasruddin, Murad, A. (2020). Influence of Problem Based Learning Models (PBL) and Learning Motivation to Learn Outcomes and Student's Critical Thinking Skills Themes of Caring for Life in Class IV Primary School No 026609 Pujidadi Binjai. Budapest International Research and Critics in Linguistics and Education (BirLE) Journal Vol 3 (4): 1634-1643.

Yusrizal, Y., Safiah, I., \& Nurhaidah, N. (2017). Kompetensi Guru Dalam Memanfaatkan Media Pembelajaran Berbasis Teknologi Informasi Dan Komunikasi (TIK) Di Sd Negeri 16 Banda Aceh. Jurnal Ilmiah Pendidikan Guru Sekolah Dasar, 2(2), 126134. 